\title{
IS POLLEN MORPHOLOGY USEFUL FOR SUPPORTING THE INFRAGENERIC CLASSIFICATION OF STILLINGIA (EUPHORBIACEAE)?
}

\author{
A MORFOLOGIA DO PÓLENÉ ÚTIL PARA APOIAR A CLASSIFICAÇÃO \\ INFRAGENÉRICA DE STILLINGIA CEUPHORBIACEAE]?
}

\author{
Sarah Maria Athiê-Souza ${ }^{1 *}$ \\ Maria Teresa Buril ${ }^{2}$ \\ André Laurênio de Melo³ \\ Marcos José da Silva ${ }^{4}$ \\ David Bogler 5 \\ Margareth Ferreira de Sales ${ }^{2}$
}

\begin{abstract}
The palynological morphology of 24 species and two subspecies of Stillingia were studied using scanning electron microscopy. The analysis was performed aiming to verify whether the pollen morphology can be helpful for identifying species and infrageneric categories in this group. Pollen grains of Stillingia are subprolate or suboblate, tricolporate, microreticulate, and psilate along the aperture margins. However, the results showed no variation between the species and demystify the importance of pollen morphology in the definition of infrageneric limits. Thus, pollen data cannot be used to distinguish species groups despite contrary indications in the literature.
\end{abstract}

Key words: Euphorbioideae, Hippomaneae, taxonomy.

\section{Resumo}

A morfologia palinológica de 24 espécies e duas subespécies de Stillingia foi estudada por microscopia eletrônica de varredura. A análise foi realizada com o objetivo de verificar se a morfologia do pólen pode ser útil na identificação de espécies e categorias infragenéricas nesse grupo. Os grãos de pólen de Stillingia são subprolados ou suboblatos, tricolporados, microreticulados e psilados ao longo das margens

1 Universidade Federal da Paraíba, Centro de Ciências Exatas e da Natureza, Departamento de Sistemática e Ecologia, 58051-90o, João Pessoa, PB, Brazil; https://orcid.org/oooo-0oo2-6090-981X

2 Universidade Federal Rural de Pernambuco, 52171-90o, Recife, PE, Brazil; email: mtburil@gmail. com; mfsales65@hotmail.com, https://orcid.org/oooo-0oo2-9587-1209

3 Unidade Acadêmica de Serra Talhada, Universidade Federal Rural de Pernambuco, 569oo-ooo, Serra Talhada, PE, Brazil; email: andrelaurenio@yahoo.com.br

4 Universidade Federal de Goiás, Instituto de Ciências Biológicas, 74001-970, Goiânia, GO, Brazil; email: marcos_agrorural@hotmail.com

5 Missouri Botanical Garden, P.O. Box 299, St. Louis, Missouri 63166-0299, U.S.A.; email: david. bogler@mobot.org

*Corresponding author: sarah_athie@yahoo.com.br 
de abertura. Entretanto, os resultados não mostraram variação entre as espécies e desmistificaram a importância da morfologia do pólen na definição dos limites infragenéricos. Assim, dados de pólen não podem ser usados para distinguir grupos de espécies, apesar de indicações contrárias na literatura.

Palavras-chave: Euphorbioidade, Hippomaneae, taxonomia.

\section{INTRODUCTION}

Euphorbiaceae s.s. encompass approximately 300 genera and 6,500 species distributed in nine major lineages, (APG IV, 2016; WURDACK et al., 2005). It is considered a eurypalynous family with several pollen types, but the most common type is tricolporate (KHAN, 1968; WEBSTER, 1994). Palynological characters often present taxonomic value, as stated by ERDTMAN (1952), the first author to recognize the importance of the pollen grain in systematic relationships within the Euphorbiaceae. WEBSTER (1975) reclassified the subfamilies and tribes using numerous morphological characters, especially those related to pollen grains. Based on his concept, each subfamily of Euphorbiaceae s.l. was characterized according to a basic pollen type. Therefore Crotonoideae has the "Croton pattern" and most species present inaperturate pollen (PUNT, 1987; WURDACK et al., 2005); Acalyphoideae present several types of pollen, although most are tricolporate or porate (PUNT, 1987); in Oldfieldioideae the pollen is homogenous, polyaperturate or pantoaperturate and spinulose (PUNT, 1987); and species of Euphorbioideae are characterized by tricolp(or)ate and tectate-perforate pollen grains (ESSER, 2001; PUNT, 1987).

Hippomaneae presents the one of the most complex taxonomy of the subfamily Euphorbioideae (WEBSTER, 1994), because the traditional generic circumscription in Hippomaneae is still based on a few floral characters, especially regarding Actinostemon Mart. ex Klotzsch, Gymnanthes Sw., Sapium P. Browne, and Sebastiania Spreng. For this reason, it is necessary to re-evaluate the classification of Hippomaneae using other features in addition to floral and vegetative traits (PAX and HOFFMANN, 1912; KRUIJT, 1996; SANTOS and SALES 2009; ESSER, 2012).

Pollen morphology of Hippomaneae has often been neglected in taxonomic studies, except in Rhodothyrsus Esser, since the pollen grain was described and considered useful to distinguish this taxon from the other in the tribe, mainly Senefeldera Mart. The palynological approach to the taxonomic study of Hippomaneae has been restricted to short descriptions (BELGRANO and POZNER, 2005; ESSER, 2001; KRUIJT, 1996; ROGERS, 1951). PUNT (1962) reported that the pollen grains of Hippomaneae are predominantly uniform, tricolporate, with the polar axis approximately $30-40 \mu \mathrm{m}$ long, with small tectum perforations, and named "Hippomane type".Stillingia is one of the largest genera of Hippomaneae, encompassing approximately 30 species distributed throughout the Americas and only one in the Paleotropical region (ROGERS, 1951; ESSER, 2001; ESSER, 2012; 
WEBSTER, 2014; ATHIÊ-SOUZA, et al., 2014, 2016). The genus is recognized by the presence of cyathiform or scutelliform foliar glands at the base of the blade, free sepals in pistillate flowers, a carpidiophore, and exarillate seeds (ROGERS, 1951; BELGRANO and POZNER, 2005; ESSER, 2012). In the most recent review of Stillingia, ROGERS (1951) used the vegetative and floral characters associated with pollen morphology to propose five infrageneric categories. According to the author, the pollen grains of Stillingia can be spheroid to ellipsoid, with 1-3 pores, and the exine can be reticulate, granular, or punctate.

Assuming that the pollen grain is a valuable character for taxa differentiation in Euphorbiaceae, this study aimed to verify whether the pollen morphology can be helpful for identifying species and infrageneric categories in Stillingia. Additionally, this study intended to provide further information about pollen morphology of this genus using scanning electron microscopy, since the last main study of Stillingia was published more than six decades ago (ROGERS, 1951).

\section{MATERIALS AND METHODS}

In the present study, 25 species of Stillingia were analyzed, including S. loranthacea (Müll. Arg.) Pax, recently reinstated by ATHIÊ-SOUZA (2014). Species known exclusively based on the types (S. dusenii Pax \& K. Hoffm. and $S$. parvifolia Sánchez Vega, Sagást. \& Huft) and those whose pollen was not available [S. bodenbenderi (O. Ktze.) D.J. Rogers, S. pietatis McVaugh, and S. querceticola McVaugh] were not analyzed. The samples were obtained from floral buds removed from specimens deposited at the Missouri Botanical Garden (MO) and the Field Museum of Natural History (F) herbaria. The anthers were macerated, mounted on metallic stubs with adhesive tape, sputter coated with gold, and examined using a JEOL 5000 scanning electron microscope at the laboratory of the Missouri Botanical Garden. For each sample, four features were studied in 15 to 20 units: pollen size and shape, number of apertures, and exine sculpture. Pollen morphology is herein described based on the terminology used by PUNT et al. (2007).

\section{RESULTS}

Species of Stillingia characteristically present monads, are isopolar, medium, radially symmetric, subprolate or suboblate, tricolporate pollen grains, colpi long and invaginated, psilate margin and microreticulate exine (Figs. 1 and 2, Table 1). The only differences among species found in this study are restricted to the shape and size of pollen grains. In most species of Stillingia pollen grains are subprolate, but in some they are suboblate (S. diphterina D. J. Rogers, S. linearifolia S. Wats., S. oppositifolia 
Müll. Arg., S. paucidentata S. Wats., S. peruviana D. J. Rogers, S. salpingadenia (Müll. Arg.) Huber, S. scutellifera D. J. Rogers, and S. texana I. M. Johnst.).

Stillingia aquatica Chapm., S. sanguinolenta Müll. Arg., S. sylvatica L., S. texana I. M. Johnst., and $S$. uleana Pax \& K. Hoffm. exhibited the largest pollen grains, with mean polar axis (P) and equatorial diameter (ED) greater than $50 \mu \mathrm{m}$ and $37 \mu \mathrm{m}$, respectively. Stillingia acutifolia (Benth) Hemsl. and S. peruviana showed the smallest pollen grains, with mean P less than or equal to $30 \mu \mathrm{m}$ (Table 1).
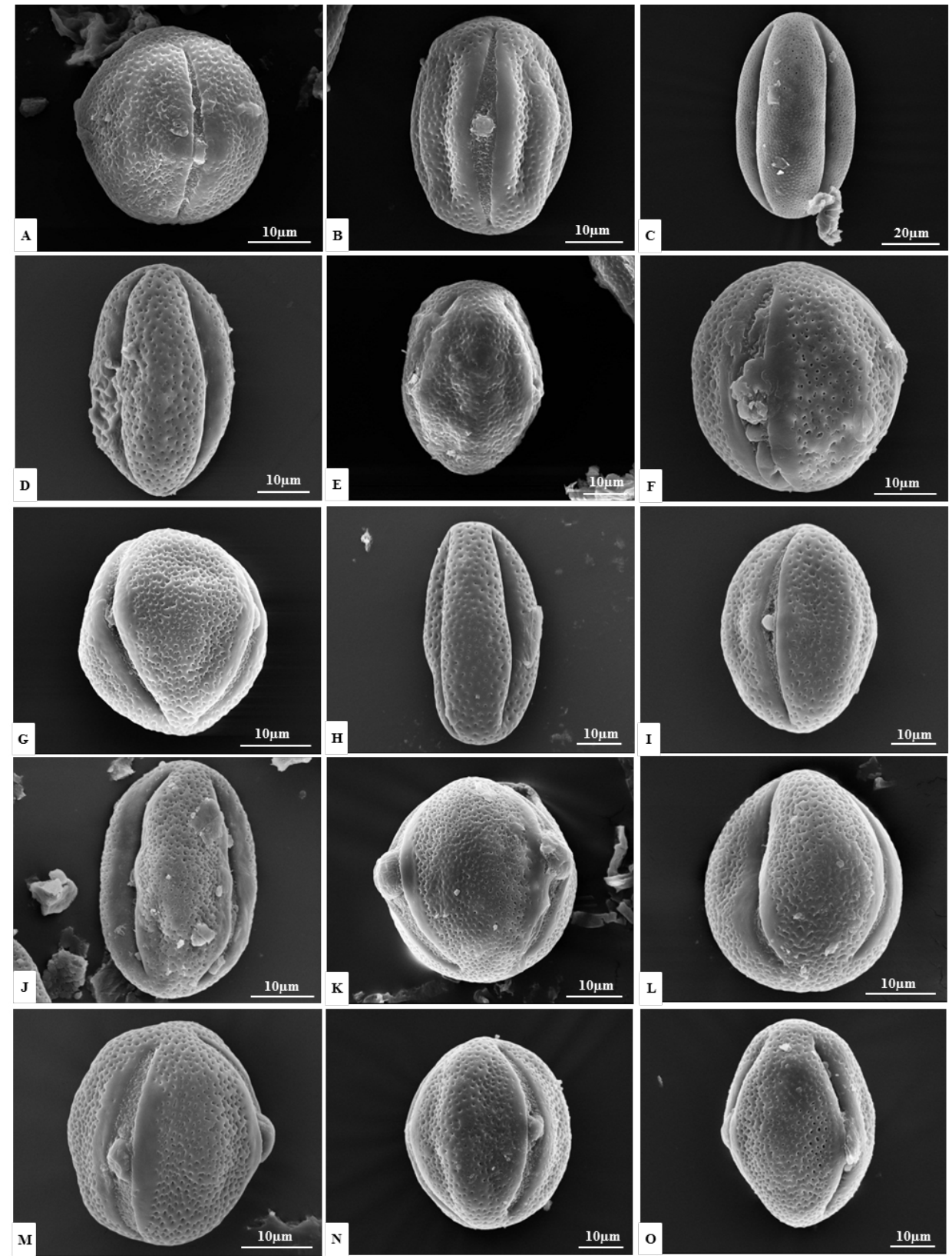

Figure 1. Scanning electron micrographs of Stillingia pollen grains. A. S. acutifolia; B.

S. argutedentata; C. S. aquatica; D. S. bicarpellaris; E. S. dichotoma; F. S. diphterina; G. S. linearifolia; H. S. lineata; I. S. loranthacea; J. S. microsperma; K. S. oppositifolia; L. S. paucidentata; M. S. peruviana; N. S. salpingadenia; O. S. sanguinolenta. 

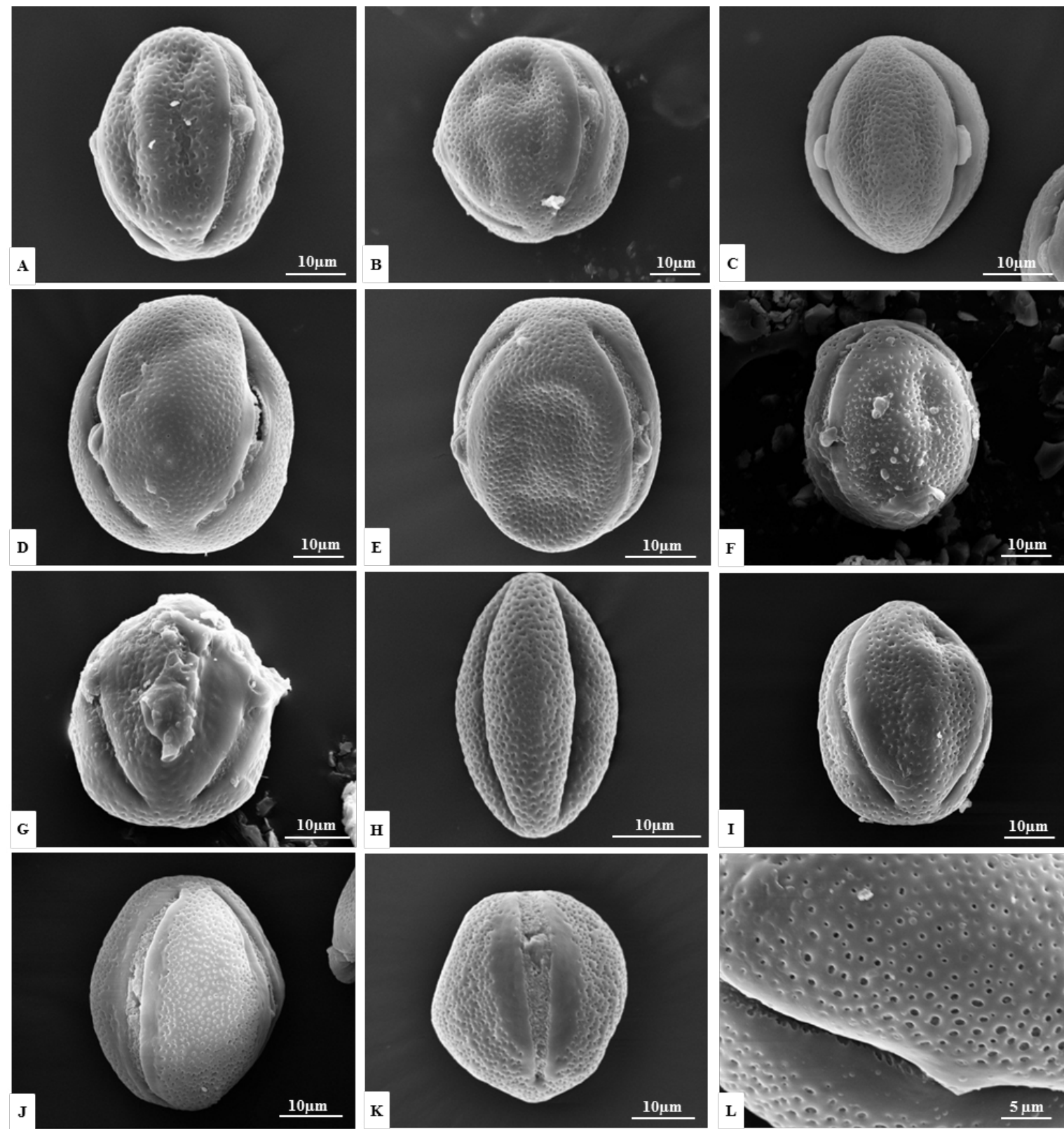

Figure 2. Scanning electron micrographs of Stillingia pollen grains. A. S. saxatilis; B. S. scutellifera; C. S. spinulosa; D. S. sylvatica; E. S. tenella; F. S. texana; G. S. trapezoidea; H. S. treculiana; I. S. uleana; J. S. zelayensis; K. S. zelayensis, showing the psilate margo; L. S. sanguinolenta, showing a magnified part of the microreticulate exine. 
Table 1. Morphological features of the pollen grains of Stillingia species. Values between parentheses correspond to the average. P: polar axis; ED: equatorial diameter.

\begin{tabular}{|c|c|c|c|c|}
\hline Species & Voucher & $\mathbf{P}(\mu \mathrm{m})$ & $\begin{array}{c}\text { ED } \\
(\mu \mathrm{m})\end{array}$ & Shape \\
\hline S. acutifolia (Benth) Hemsl. & $\begin{array}{l}\text { A. Mendez Ton et al. } 9840 \\
\text { (MO) }\end{array}$ & $25(29) 33$ & $27(30) 33$ & Suboblate \\
\hline S. aquatica Chapm. & $\begin{array}{l}\text { W. L. Applequist et al., } 20 \\
\text { (MO) }\end{array}$ & $53(68) 75$ & $30(38) 44$ & Subprolate \\
\hline S. argutedentata Jabl. & R. M. Harley et al., 25207 (MO) & $29(37) 40$ & $28(30) 37$ & Subprolate \\
\hline S. bicarpellaris S. Wats. & F. Chiang et al., 8130 (MO) & $39(41) 44$ & $26(27) 28$ & Subprolate \\
\hline S.dichotoma Müll. Arg. & $\begin{array}{l}\text { H. Q. B. Fernandes et al., } 1913 \\
\text { (MO) }\end{array}$ & $41(43) 45$ & $29(31) 32$ & Subprolate \\
\hline S. diphterina D. J. Rogers & G. Davidse et al., 35154 (MO) & $34(37) 39$ & $32(34) 35$ & Suboblate \\
\hline S. linearifolia S. Wats. & C. Dietrich et al., 12 (MO) & $28(35) 40$ & $26(32) 35$ & Suboblate \\
\hline $\begin{array}{l}\text { S. lineata subsp. lineata } \\
\text { (Lam.) Müll. Arg. }\end{array}$ & D. Lorence et al., 2265 (MO) & $33(38) 50$ & $19(22) 27$ & Subprolate \\
\hline $\begin{array}{l}\text { S. lineata subsp. pacifica } \\
\text { (Müll. Arg.) Steenis }\end{array}$ & $\begin{array}{c}\text { G. L. Webster E R. Hildreth, } \\
14396(\mathrm{MO})\end{array}$ & $32(38) 47$ & $21(23) 28$ & Subprolate \\
\hline $\begin{array}{l}\text { S. loranthacea (Müll. Arg.) } \\
\text { Pax }\end{array}$ & P. Tavares et al., 30 (MO) & $42(45) 47$ & $33(35) 41$ & Subprolate \\
\hline $\begin{array}{l}\text { S. microsperma Pax \& K. } \\
\text { Hoffm. }\end{array}$ & Rzedowsky, 46711 (MO) & $34(36) 38$ & $22(23) 24$ & Subprolate \\
\hline S. oppositifolia Müll. Arg. & R. Wasum et al., 12048 (MO) & $34(35) 37$ & $31(32) 34$ & Suboblate \\
\hline S. paucidentata S. Wats. & M. Kerr s.n. (F 1485056) & $27(31) 35$ & $26(28)_{31}$ & Suboblate \\
\hline S. peruviana D. J. Rogers & P. C. Hutchison 1682 (MO) & $29(30) 31$ & $25(26) 27$ & Suboblate \\
\hline $\begin{array}{l}\text { S. salpingadenia (Müll. Arg.) } \\
\text { Huber }\end{array}$ & G. Hatschbach, 23844 (MO) & $38(41) 44$ & $32(34) 37$ & Suboblate \\
\hline S. sanguinolenta Müll. Arg. & T. C. Frye et al., 2493 (MO) & $44(53) 59$ & $30(36) 40$ & Subprolate \\
\hline S. saxatilis Müll. Arg. & H. S. Irwin et al., $2255^{2}(\mathrm{MO})$ & $40(42) 44$ & $33(35) 38$ & Subprolate \\
\hline S. scutellifera D. J. Rogers & E. M. Zardini et al., 51146 (MO) & $40(43) 46$ & $32(37) 42$ & Suboblate \\
\hline S. spinulosa Torr. & L. M. Schultz et al., $8242(\mathrm{MO})$ & $29(31) 34$ & $25(26) 28$ & Subprolate \\
\hline S. sylvatica L. & S. B Jones, 25212 (MO) & $42(57) 75$ & $30(39) 45$ & Subprolate \\
\hline $\begin{array}{l}\text { S. tenella (Pax E K. Hoffm.) } \\
\text { Esser }\end{array}$ & Morrone et al., 4417 (MO) & $34(36) 38$ & $29(30) 32$ & Subprolate \\
\hline S. texana I. M. Johnst. & J. S. Miller, $6324(\mathrm{MO})$ & $42(54) 61$ & $35(37) 43$ & Suboblate \\
\hline S. trapezoidea Ule & F. Villarouco et al., 75 (MO) & $34(37) 39$ & $31(32) 33$ & Subprolate \\
\hline $\begin{array}{l}\text { S. treculiana (Müll. Arg.) I. } \\
\text { M. Johnst. }\end{array}$ & J. S. Miller, 6315 (MO) & $29(32) 34$ & $18(20) 21$ & Subprolate \\
\hline S. uleana Pax \& K. Hoffm. & $\begin{array}{l}\text { P. L. R. Moraes et al., } 2895 \\
\text { (MO) }\end{array}$ & $44(50) 57$ & $33(37) 46$ & Subprolate \\
\hline $\begin{array}{l}\text { S. zelayensis (Kunth) Müll. } \\
\text { Arg. }\end{array}$ & P. P. Moreno, 16719 (MO) & $36(47) 51$ & $30(36) 39$ & Subprolate \\
\hline
\end{tabular}




\section{DISCUSSION}

The species of Stillingia assessed in this study seem to be palynologically homogeneous since they have the same exine ornamentation and number of apertures (Figs. 1 and 2). Our results corroborate the description of Hippomaneae proposed by WEBSTER (1994), which includes specimens with tricolporate pollen grains, colpi usually marginate, and sexine perforate. BELGRANO and POZNER (2005) described S. yungasensis, originally from Argentina and Bolivia, and reported similar results, i.e. subprolate and tricolporate pollen grains, with tectate and micropunctate exine. WEBSTER (2014) mentioned that tricolpate pollen grains with semitectate exine represent a plesiomorphic character in Euphorbiaceae. Reticulate exine is normally found in Euphorbioideae and this character can be correlated with entomophilous pollination (THIN, 2007).The results obtained in this study support and reinforce the concept of the "Hippomane type" stated by PUNT (1962). According to ESSER (2012), the pollen grain in the tribe Hippomaneae is homogeneous, with a few exceptions (i.e. Rhodothyrsus). Although ESSER (2012) found some morphological variations in his studies of Mabea, these differences were not taxonomically relevant. CRUZ-BARROS et al. (2006) observed the same pattern of exine ornamentation and apertures in Actinostemon concolor and Microstachys corniculata (Vahl) A. Juss. ex Griseb.

The taxa with suboblate pollen grains reported in this study (S. diphterina, S. linearifolia, S. oppositifolia, S. paucidentata, S. peruviana, S. salpingadenia, S. scutellifera, and $S$. texana) were classified by ROGERS (1951) in different subgenera and three series and do not share taxonomic relationships, since they do not show morphological similarity or any geographical evidence which could gather them in a sole group. Although some variations in the size of pollen grains have been registered, this is not a taxonomically informative character.

Therefore, in Stillingia, pollen characteristics do not seem to be associated with macromorphological characters and, due to this, they are not useful for establishing groups. During the revision of Stillingia, which was conducted by the first author, it was possible to evidence that, besides pollen characteristics, other features used by ROGERS (1951) to characterize species of Stillingia are also arbitrary and difficult to distinguish (e.g. texture of branches). Consequently, only phylogenetic analyses may provide consistent data to verify the existence of infrageneric categories in Stillingia.

Additionally, the taxonomic treatment undertaken by ROGERS (1951) differed from the findings of the present study, because the author reported spheroid to ellipsoid pollen grains, with 1-3 pores and reticulate, granular, or punctate exine. The misconception of ROGERS (1951) has been perpetuated and ESSER (2001) already commented this. Traditionally, the palynological characters of Stillingia have been indicated as diagnostic criteria to determine infrageneric categories and distinguish species within the genus (ROGERS, 1951).

ROGERS (1951) established the series of Stillingia based on vegetative and floral characters such as habit, appearance of stem and petioles, venation and texture 
of leaves, and presence of caruncle, in addition to pollen grain features such as shape, number of apertures, and exine sculpture (Table 2). ROGERS (1951) also stated that the series of Stillingia normally has spheroid and 3-porate pollen grains, with some exine variations and some other peculiarities such as pollen grain shallowly or deeply 3-segmented, with circular or triangular cross-section, or showing the exine unevenly striate. The pollen grains of Dichotomae are quite different, because they are ellipsoid with one lateral pore. Furthermore, the author differentiated some groups of species taking the morphology of the pollen grain into consideration (Table 3). Among the 23 species studied by ROGERS (1951), S. dichotoma, S. saxatilis, and S. uleana have uniporate pollen grains and exine ornamentation ranging from reticulate to punctate or granular. The remaining species exhibit 3-porate pollen grains with exine also ranging from reticulate to punctate or granular. It is important to emphasize that these groups of species are not natural and do not show any taxonomic relationships, except for four species that belong to the series Dichotomae and have succulent stems and leaves (Table 2).

Table 2. Diagnostic characteristics of Stillingia series according to ROGERS (1951).

\begin{tabular}{|c|c|}
\hline Series & Diagnostic characteristics \\
\hline Acutifoliae & $\begin{array}{l}\text { Shrubs or small trees, leaves distinctly petiolate, pinnate venation prominent, } \\
\text { pollen grains spheroid or ellipsoid, ecarunculate seeds }\end{array}$ \\
\hline Dichotomae & $\begin{array}{l}\text { Stems mostly succulent, leaves succulent, pollen grains ellipsoid with one } \\
\text { lateral pore }\end{array}$ \\
\hline Oppositifoliae & $\begin{array}{l}\text { Woody stems, membranous or leathery leaves, pollen grains spheroid with } \\
\text { three pores }\end{array}$ \\
\hline Sylvaticae & $\begin{array}{l}\text { Subshrubs arising from an enlarged woody base, stems mostly annual or } \\
\text { biennial, herbaceous or sub-herbaceous, green to reddish-brown, usually } \\
\text { without lenticels }\end{array}$ \\
\hline Treculianae & $\begin{array}{l}\text { Perennial herbs, leaves sessile to subsessile, venation non prominent, pollen } \\
\text { grains spheroid, 3-segmented, with three pores, ecarunculate to carunculate } \\
\text { seeds }\end{array}$ \\
\hline
\end{tabular}

Table 3. Morphology of the pollen grains of each Stillingia species according to ROGERS (1951).

\begin{tabular}{lll}
\hline \multicolumn{1}{c}{ Species } & \multicolumn{1}{c}{ Series } & \multicolumn{1}{c}{ Morphology of pollen grains } \\
S. acutifolia & Acutifoliae & $\begin{array}{l}\text { Ellipsoid to spheroid, triangular in cross-section, } \\
\text { with three pores, exine finely punctate }\end{array}$ \\
S. aquatica & Oppositifoliae & $\begin{array}{l}\text { Ellipsoid to ovoid, with three pores, exine coarsely } \\
\text { punctate }\end{array}$ \\
S. bicarpellaris & Oppositifoliae & $\begin{array}{l}\text { Nearly spheroid, with three segments, three pores, } \\
\text { exine granular to reticulate }\end{array}$ \\
S. bodenbenderi & Oppositifoliae & $\begin{array}{l}\text { Irregularly ovoid, with three pores, exine reticulate } \\
\text { to granular }\end{array}$
\end{tabular}




\begin{tabular}{|c|c|c|}
\hline Species & Series & Morphology of pollen grains \\
\hline S. dichotoma & Dichotomae & $\begin{array}{l}\text { Ellipsoid, triangular in cross-section, with one } \\
\text { lateral pore, exine finely to coarsely punctate }\end{array}$ \\
\hline S. diphterina & Oppositifoliae & Spheroid, with three pores, exine granular \\
\hline S. dusenii & Sylvaticae & $\begin{array}{l}\text { Irregularly spheroid, with three pores, exine } \\
\text { granular to coarsely punctate }\end{array}$ \\
\hline S. linearifolia & Treculianae & $\begin{array}{l}\text { Spheroid to irregularly ellipsoid, broadly triangular } \\
\text { in cross-section, with three pores, exine finely } \\
\text { punctate }\end{array}$ \\
\hline S. microsperma & Oppositifoliae & $\begin{array}{l}\text { Spheroid to ellipsoid, circular in cross-section, with } \\
\text { three pores, exine finely punctate }\end{array}$ \\
\hline S. oppositifolia & Oppositifoliae & Spheroid, with three pores, exine coarsely reticulate \\
\hline S. paucidentata & Treculianae & $\begin{array}{l}\text { Spheroid, shallowly 3-segmented, with three pores, } \\
\text { exine coarsely punctate }\end{array}$ \\
\hline S. peruviana & Oppositifoliae & Spheroid, with three pores, exine granular \\
\hline S. salpingadenia & Sylvaticae & $\begin{array}{l}\text { Ovoid to ellipsoid, with three pores, exine unevenly } \\
\text { striate to granular }\end{array}$ \\
\hline S. sanguinolenta & Oppositifoliae & $\begin{array}{l}\text { Ellipsoid, circular in cross-section, with three pores, } \\
\text { exine reticulate to coarsely punctate }\end{array}$ \\
\hline S. saxatilis & Dichotomae & Ellipsoid, with one lateral pore, exine granular \\
\hline S. scutellifera & Sylvaticae & Spheroid, with three pores, exine granular \\
\hline S. spinulosa & Treculianae & $\begin{array}{l}\text { Ellipsoid, triangular in cross-section, with three } \\
\text { pores, exine finely to coarsely punctate }\end{array}$ \\
\hline S. sylvatica & Sylvaticae & $\begin{array}{l}\text { Ellipsoid to spheroid, with three pores, exine } \\
\text { reticulate to granular }\end{array}$ \\
\hline S. texana & Sylvaticae & $\begin{array}{l}\text { Mostly spheroid, with three pores, exine granular to } \\
\text { reticulate }\end{array}$ \\
\hline S. trapezoidea & Dichotomae & Not seen by Rogers (1951) \\
\hline S. treculiana & Treculianae & $\begin{array}{l}\text { Spheroid, deeply } 3 \text {-segmented, with three pores, } \\
\text { exine coarsely punctate }\end{array}$ \\
\hline S. uleana & Dichotomae & Ellipsoid, with one pore, exine coarsely reticulate \\
\hline S. zelayensis & Sylvaticae & Spheroid, with 3 pores, exine reticulate \\
\hline
\end{tabular}




\section{CONCLUSIONS}

The genus Stillingia is herein considered stenopolinic, corroborating the results reported by KHAN (1968) and WEBSTER (1994) for Euphorbiaceae and by PUNT (1962), WEBSTER (1994), and ESSER (2012) for Hippomaneae. Our results suggest that pollen features are not taxonomically informative characters, and therefore cannot be used to distinguish species or series as it has been traditionally adopted since ROGERS (1951) published his study. In addition, the pollen grains of three species of Stillingia are described here for the first time. Nevertheless, further palynological investigations of species belonging to the tribe Hippomaneae are still necessary.

\section{AUTHORS' CONTRIBUTIONS}

S.M.A.S. generated data, interpreted the results and wrote the manuscript. M.T.B. and A.L.M. contribute to the correction and discussion of the results. M.J.S. reviewed the text. D.B. assisted in the palynological analyzes. M.F.S. contribute to the correction and to research funding.

\section{ACKNOWLEDGEMENTS}

Wewould liketothankthefunding provided by Conselho NacionaldeDesenvolvimento Científico e Tecnológico (CNPq 141308/2011-7) and Coordenação de Aperfeiçoamento de Pessoal de Nível Superior (CAPES/PDSE 8217/12-2) for a PhD grant and the financial support during a visit to the United States, respectively. We are also grateful to the REFLORA project entitled "Sistemática, filogenia e acervo virtual de coleções tipo de Euphorbiaceae, com ênfase nas tribos Hippomaneae, Hureae e Crotoneae" (CNPq 563571/2010-1), to the project of Capes/PNADB (230380ooo33/2010-16), to the curators of the herbaria $\mathrm{F}$ and $\mathrm{MO}$ for allowing us to sample the specimens.

\section{REFERENCES}

APG 2016 - An update of the Angiosperm Phylogeny Group classification for the orders and families of flowering plants: APG IV. Botanical Journal of the Linnean Society 181: $1-20$. 
ATHIÊ-SOUZA, S.M., MELO, A.L., SILVA, M.J. and SALES, M.F. 2014 - Reinstatement and lectotypification of Stillingia loranthacea (Euphorbiaceae), a vulnerable species from Chapada Diamantina, Bahia (Brazil), and a new circumscription of Stillingia saxatilis. Systematic Botany 39: 510-516.

ATHIÊ-SOUZA, S.M., MELO, A.L., SILVA, M.J. and SALES, M.F. 2016 - New synonyms and typifications of Stillingia (Euphorbiaceae). Phytotaxa 266 (3): 183-194.

BELGRANO, M.J. and POZNER, R. 2005 - Stillingia yungasensis (Euphorbiaceae): a new species from Northwestern Argentina and Southern Bolivia. Systematic Botany 30: 134-138.

CRUZ-BARROS, M.A.V., CORRÊA, A.M.S. e MAKINO-WATANABE, H. 2006 - Estudo polínico das espécies de Aquifoliaceae, Euphorbiaceae, Lecythidaceae, Malvaceae, Phytolaccaceae e Portulacaceae ocorrentes na restinga da Ilha do Cardoso (Cananéia, SP, Brasil). Revista Brasileira de Botânica 29: 145-162.

ERDTMAN, G. 1952 - Pollen morphology and plant taxonomy, Angiosperms Almqvist and Wiksell, Stockholm, 539 p.

ESSER, H.-J. 2001 - Tribes Hippomaneae, Hureae, Pachystromateae ; pp. 352-397. In: Radcliffe-Smith, A. (Ed.) Genera Euphorbiacearum. Royal Botanic Gardens, Kew..

ESSER, H.-J. 2012 - The tribe Hippomaneae (Euphorbiaceae) in Brazil. Rodriguésia 63: 209-225.

KHAN, H.A. 1968 Contributions to the pollen morphology of the Euphorbiaceae. Journal of Palynology 4: 21-35.

KRUIJT, R.C. 1996 A taxonomic monograph of Sapium Jacq., Anomostachys (Baill.) Hurus., Duvigneaudia J. Léonard and Sclerocroton Hochst. (Euphorbiaceae tribe Hippomaneae). Bibliotheca Botanica, $109 \mathrm{p}$.

PAX, F. and HOFFMANN, K. 1912 - Euphorbiaceae-Hippomaneae. In: Engler, A. (Ed.) Das Pflanzenreich IV.147.V (Heft 52). W. Engelmann, Leipzig, 319 p.

PUNT, W. 1962 - Pollen morphology of the Euphorbiaceae with special reference to taxonomy. Wentia 7: 1-116.

PUNT, W. 1987 - A survey of pollen morphology in Euphorbiaceae with special reference to Phyllanthus. Botanical Journal of the Linnean Society 94: 127-142.

PUNT, W., HOEN, P.P., BLACKMORE, S., NILSSON, S. and LE THOMAS, A. 
2007 - Glossary of pollen and spore terminology. Review of Palaeobotany and Palynology 143: 1-81.

ROGERS, D.J. 1951 - A revision of Stillingia in the New World. Annals of the Missouri Botanical Garden 38: 207-259.

SANTOS, V.J. and SALES, M.F. 2009 - A tribo Hippomaneae A. Juss. ex Spach. (Euphorbiaceae Juss.) no estado de Pernambuco, Brasil. Acta Botanica Brasilica 23: 976-990.

THIN, N.N. 2007 - Taxonomy of Euphorbiaceae in Vietnam. Vietnam National University Publishers, Hanoi, 407 p.

WEBSTER, G.L. 1983 - A botanical Gordian knot: the case of Ateramnus and Gymnanthes (Euphorbiaceae). Taxon 32: 304-305.

WEBSTER, G.L. 1994 - Classification of the Euphorbiaceae. Annals of the Missouri Botanical Garden 81: 3-32.

WEBSTER, G.L. 1975 - Conspectus of a new classification of the Euphorbiaceae. Taxon 24: 593-601.

WEBSTER, G.L. and HUFT, M.J. 1988 - Revised synopsis of Panamanian Euphorbiaceae. Annals of the Missouri Botanical Garden 75: 1087-1144.

WEBSTER, G. L. 1994 - Classification of the Euphorbiaceae. Annals of the Missouri Botanical Garden 81: 3-32.

WEBSTER, G.L. 2014 - Euphorbiaceae; pp. 51-216. In: Kubitzki, K. (Ed.) The families and genera of vascular plants 11. Springer-Verlag, Berlin.

WURDACK, K.J., HOFFMANN, P. and CHASE, M.W. 2005 - Molecular phylogenetic analysis of uniovulate Euphorbiaceae (Euphorbiaceae sensu stricto) using plastid $r b c L$ and trnL-F DNA sequences. American Journal of Botany 92: 1397-1420. 